\title{
Second Times Picomole per Milliliter
}

National Cancer Institute

\section{Source}

National Cancer Institute. Second Times Picomole per Milliliter. NCI Thesaurus. Code C85813.

Seconds times picomoles per milliliter. 